\title{
ANTÓNIO VIEIRA REPAGINADO: A \\ CONSTRUÇÃO ARGUMENTATIVA \\ E NARRATIVA NA ADAPTAÇÃO \\ DE SERMÕES PARA HISTÓRIAS EM \\ QUADRINHOS
}

Saulo Gomes Thimoteo ${ }^{1}$

\begin{abstract}
Resumo: Os textos do padre António Vieira, especialmente os sermões, são consideradas obras de grande interesse literário, devido à sua cadência verbal, seus jogos de imagens, ideias e conceitos, como se fosse uma construção que se faz aos olhos do leitor. Utilizando-se dos processos de adaptação, é possível revisitar a obra vieiriana, ilustrando os raciocínios de argumentação e as alegorias e exemplos em forma de história em quadrinhos. Com isso, esta pesquisa pretende elaborar materiais que, por meio da junção das linguagens verbal e não verbal, funcionem tanto como uma porta de entrada para leitores neófitos, quanto como uma oportunidade de releitura aos já conhecedores da obra do padre Vieira.
\end{abstract}

Palavras-chave: Padre António Vieira; adaptação; História em quadrinhos

\section{ANTÓNIO VIEIRA REPAGINATED: THE ARGUMENTATIVE AND NARRATIVE CONSTRUCTION IN THE ADAPTATION OF SERMONS TO GRAPHIC NOVELS}

\begin{abstract}
The texts of Father António Vieira SJ, specially his sermons, are considered works of major literary interest, due to their games of images, ideas and concepts, as if it was a building that made itself in front of the reader's eyes. Using adaptation methods, it is possible to revisit the Vieira texts, illustrating the argumentation thought and the allegories and examples in the form of a comic-book story. Therefore, this research intents to elaborate materials that work, by the junction of the verbal and non-verbal languages, as an entrance door to the new readers but also as an opportunity to re-reading to the experts of Father Vieira's work.
\end{abstract}

Key-words: Father António Vieira SJ; adaptation; Graphic novels.

\footnotetext{
1 Professor Adjunto III de Teoria Literária e Literatura na Universidade Federal da Fronteira Sul - UFFS, campus de RealezaPR, desde 2011. Doutor em Letras pela Universidade de São Paulo - USP. E-mail saulo.thimoteo@uffs.edu.br
} 
Ao longo das duas primeiras décadas do século XXI, observa-se uma tendência cada vez maior, no que concerne ao trabalho escolar com a literatura, de atender a duas forças antagônicas: por um lado, há um aluno-leitor continuamente conectado e que parece distanciar-se das formas tradicionais da recepção do texto literário; por outro, há toda uma tradição literária (brasileira, lusófona, ocidental) que se deve dar a conhecer, por constituir-se como elemento cultural basilar de formação para qualquer pessoa.

Como o Arlequim de Carlo Goldoni, o professor deve servir a esses "dois amos", ambos desejando a primazia, e mostrar os ganhos existentes em tal diálogo. Os recursos para tal são abundantes: adaptações cinematográficas e televisivas de qualidade; atividades lúdicas como jogos e dinâmicas que remetem ao universo criado pelos escritores; histórias em quadrinhos baseadas em clássicos da literatura. Em tudo isso, tão importante quanto o texto-base é o processo adaptativo, que deve garantir um equilíbrio da essência e da construção do original com o repertório possível do seu leitor/espectador/ usuário (que pode ir desde o total desconhecimento até a leitura em profundidade).

Nesse sentido, a proposta elaborada no Projeto de Pesquisa "Sermões aos quadradinhos: processos de adaptação de obras do padre António Vieira para HQs", produzida aolongo de 2018, como parte de um projeto maior, em desenvolvimento desde 2015, é aproximar dois gêneros textuais, a princípio, antagônicos, como os sermões e a história em quadrinhos, de modo a revelar como as construções verbais e argumentativas do padre António Vieira (1608-1697) ainda reverberam e se podem tornar produtoras de sentidos às novas gerações, mesmo com mais de quatro séculos de distância ${ }^{2}$.

2 Até o momento, sete HQs foram produzidas pelo projeto no sítio de criação www.pixton.com: Sermão da Sexagésima, Sermões das Quatro Domingas do Advento (1650), Sermão
Cada época possui uma recepção mais proeminente a alguns gêneros e mídias em detrimento de outros. No caso do século XVII, em que Vieira se situa, não havia imprensa nem mesmo o livro como bem de consumo usual. Assim, a oratória do púlpito tornava-se fundamental veículo de religiosidade, informação e até mesmo de fruição estética. No entanto, no século XXI, a parenética não encontra o mesmo respaldo e prestígio, embora a mesma força e assertividade dessas falas ainda se mantenham.Um leitor atual, no contato com tais textos, pode, inicialmente, oferecer certa resistência, em especial no ambiente escolar com crianças ou adolescentes. Por essa razão, a adaptação para outra mídia (mas mantendo-se a essência e a narrativa global) torna-se um caminho complementar possível de representação e interpretação do texto original, uma vez que se busca transmitir a essência da mensagem pretendida, mas por outros canais ou com outras linguagens.

Ao se observar a literatura em sua dinâmica entre épocas e estilos, mecanismos de evocação, referência e transmutação de histórias anteriores acompanham todas as culturas, basta apontar como a mitologia greco-romana apresenta-se, ainda hoje, nos mais diversos espaços e meios. Da mesma forma que a Bíblia se apresenta não somente como um dos livros fundamentais de todo o pensamento ocidental, mas como fonte de personagens e cenas que habitam o conhecimento comum de cultura geral. Tanto essas histórias ancestrais e mitológicas, quanto as terrenas e comezinhas, todas estão passíveis de sofrerem uma "reapropriação", no sentido de se ressignificarem e darem-se a conhecer por novas formas a novos públicos.

do Bom Ladrão e Sermão de Santo António (1655). Todas estão disponíveis no sítio: http://cidh-global.org/sermoesdo-padre-antonio-vieira-em-banda-desenhada/ e em http:// vieiranaveia.blogspot.com (para download em PDF). Encontra-se em fase de elaboração uma HQ sobre aspectos biográficos de António Vieira, fazendo uma associação entre o século XVII e XXI. 
Pensando nisso, Linda Hutcheon, em Uma teoria da adaptação, problematiza as questões concernentes às adaptações e às evocações das narrativas e obras no processo diacrônico em que se vão sucedendo:

\begin{abstract}
As histórias não são imutáveis; ao contrário, elas também evoluem por meio da adaptação ao longo dos anos. Em alguns casos, tal como ocorre na adaptação biológica, a adaptação cultural conduz a uma migração para condições mais favoráveis: as histórias viajam para diferentes culturas e mídias. (HUTCHEON, 2013, p. 58)
\end{abstract}

Tal processo "darwinista" de adaptação das histórias é uma abordagem possível para o fenômeno da transposição de romances em filmes e séries, uma vez que o universo criado por um autor se pode ramificar em infinitas narrativas, expressas nos mais variados formatos, por vezes até indo além do próprio texto original. Mas, para que tal evolução se desenvolva de modo coerente e válido, é preciso que as novas produções não se estabeleçam como pretensas cópias nem tampouco como textos novos e desconectados do original. Esses são alguns dos desafios que a adaptação pode enfrentar, justamente por ter de confluir, em um texto novo, as informações principais do texto original a serem compreendidas e formar uma unidade de sentido para um leitor neófito.

$\mathrm{O}$ intuito de tais histórias em quadrinhos a partir de sermões de António Vieira, então, é de se tornarem exercícios para uma nova experiência de leitura com os seus textos. Há diversos aspectos de sua vida e obra que podem ser apresentados: os sermões (mais conhecidos e cujos trechos principais usualmente aparecem nas aulas de Ensino Médio sobre o período Barroco), as profecias (parcela pouco explorada, mas que o próprio Vieira considerava um "palácio" diante das "simples choupanas" que seriam os seus sermões), a sua Defesa perante o tribunal do Santo Ofício (no seu processo por heresia, derivado das profecias feitas, em que acabou condenado, conseguindo reverter a sentença posteriormente, com um indulto do próprio Papa), a sua biografia de missionário e político em contínuo movimento, cruzando o Atlântico por diversas vezes, inclusive com ataques de corsários, percorrendo o Norte e o Nordeste brasileiros, criando acordos (e desacordos) com Holanda e Castela.

Como se nota, muitos elementos podem ser apresentados aos alunos, para além de trechos do Sermão da Sexagésima ou do Sermão do Bom Ladrão e uma breve biografia de dados. Essas adaptações para histórias em quadrinhos pressupõem, então, uma estratégia de "tradução" na junção das linguagens verbal e não verbal, com vistas a articular o contexto social e histórico de produção de António Vieira no século XVII em uma estrutura narrativa.

Barbara Postema, em Estrutura narrativa nos quadrinhos, analisa uma série de elementos da composição de quadrinhos para transmitir uma história. Tendo como um dos tópicos de discussão a questão dialética de cada imagem ser detentora de certa unidade, mas que só adquire pleno significado quando posta num encadeamento com outras imagens, a autora salienta que

$$
\begin{aligned}
& \text { os quadros (ou vinhetas), nos quadrinhos, } \\
& \text { deveriam ser vistos de forma sintagmática, } \\
& \text { como unidades criando uma estrutura maior. } \\
& \text { Internamente, a unidade do quadro sustenta } \\
& \text { todos os códigos visuais mais importantes, } \\
& \text { entre eles o código icônico, assim como } \\
& \text { os códigos de expressão facial, gestual, de } \\
& \text { perspectiva, e outros. As imagens dentro dos } \\
& \text { quadros se tornam unidades de significação } \\
& \text { discretas que devem ser abordadas e } \\
& \text { decodificadas uma de cada vez. (POSTEMA, } \\
& \text { 2018, p. 20) }
\end{aligned}
$$

Nessa dualidade entre construção unitária e panorama de coesão global reside o desafio contínuo do trabalho de elaboração de histórias em quadrinhos, uma vez que se deve garantir ao leitor a compreensão tanto dos elementos que integram o quadro (a fala, as expressões e o posicionamento dos personagens, os adereços que compõe a cena), 
quanto da linearidade sugerida com os quadros anteriores e posteriores (a evolução do raciocínio que as falas encetam, as novas situações que se somam, as reações dos personagens). No caso das HQ elaboradas em torno dos sermões de António Vieira, houve tais cuidados para distribuir as informações constantes nos argumentos apontados pelo padre de modo a garantir a legibilidade de cada quadrinho, da mesma forma que produzir uma sequência lógica que evocasse a vazão argumentativa desenvolvida em cada sermão.

Um terceiro pormenor importante diz respeito à linguagem e ao contexto do século XVII e como isso se torna ponto de análise e discussão, no processo de adaptação da obra. Assim, a partir de leituras sobre a mentalidade e a sociedade da época de António Vieira, em textos como O teatro do sacramento, de Alcir Pécora, ou $O$ discurso engenhoso, de António José Saraiva, monta-se um panorama do pensamento vieiriano, tornando-se ponto de partida para as demais etapas práticas de elaboração das $\mathrm{HQ}$, a saber: 1) escolha e estudo de um sermão, associando-o com fortuna crítica e análise estrutural; 2) síntese dos argumentos, conceitos e imagens nas partes constitutivas do sermão, à guisa de capítulos; 3) adaptação em roteiro dos trechos do texto e disposição possível dos elementos a constarem em cada quadrinho; 4) definição das imagens, como jogo de texto verbal e não-verbal; 5) construção da adaptação a partir de sítio de criação de história em quadrinhos.

A produção de tais materiais tem como meta tornar-se ponto de acesso aos textos originais de António Vieira. Conforme as atuais discussões dos espaços de leitura e de multimodalidades, não se deve estabelecer uma hierarquização das linguagens, como se as histórias em quadrinhos estivessem em nível inferior do que a literatura exclusivamente verbal, mas sim tratar ambos os gêneros como competências comunicacionais distintas (cf. WIELEWICKI; PRADO, 2019, p. 436). Assim, a utilização das HQs, no contexto educacional, mobilizará uma série de competências que não seriam, necessariamente, acionadas apenas com o texto parenético original, mas de modo algum elas o suplantam ou o substituem. Antes funcionam como hommage, desejando tanto despertar a curiosidade pela leitura posterior do sermão referido, quanto funcionar como rememoração das falas vieirianas em outro formato.

Um exemplo é o processo desenvolvido na adaptação em HQ do Sermão da Sexagésima. Tomando como base o versículo bíblico da parábola do semeador ("Ecce exït quid seminat seminare semen sum”), Vieira associará a cinco circunstâncias que todo pregador deve ter:
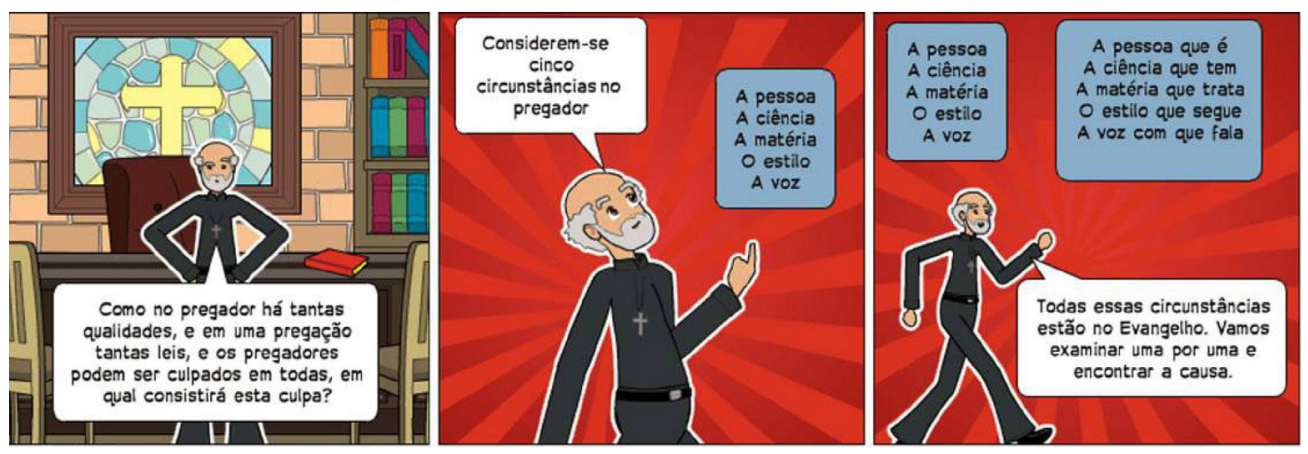

Figura 1: Quadrinhos da HQ Sermão da Sexagésima, página 3.

Citou-se ipsis litteris a primeira frase da parte IV do Sermão, pois, com relação à linguagem vieiriana, uma das principais intenções das HQs não é a "facilitação" do texto por meio de uma mera troca de 
palavras, mas inserir um contexto ilustrativo para tal discurso, por meio de cenários e expressões dos personagens. Com relação ao texto original subsequente, exceto por pontuais mudanças verbais, manteve-se a mesma estrutura e disposição: "No pregador podem-se considerar cinco circunstâncias. (...) Todas estas circunstâncias temos no Evangelho. Vamo-las examinando uma por uma, e buscando esta causa." (VIEIRA, 2015, p. 53). No quadrinho inicial correspondente a essa parte, estabeleceu-se o cenário de uma sala, com o personagem dirigindose ao seu leitor, visando a replicar o movimento do sermão sendo pronunciado. Nos dois quadrinhos seguintes, elaborados em um cenário neutro, mas com apelo visual que cria uma noção de perspectiva, sintetizou-se um quadro explicativo das cinco circunstâncias, explorando um aspecto mais didático de tal apresentação.

Um processo que tanto é utilizado pelo padre António Vieira em seus sermões, quanto serviu de diretriz para a adaptação para HQs é a noção de "claves", algo usado desde a Idade Média e que se realiza, conforme define António José Saraiva em $O$ discurso engenhoso: "Encontram-se, no texto escolhido para o sermão, as claves ou palavraschave, cuja análise permitia compreender o sentido, tirar ensinamentos e estabelecer ligações entre diferentes passagens da Escritura." (SARAIVA, 1980, p. 118). No caso da Sexagésima, anteriormente mencionado, a progressão interna dá-se em torno das circunstâncias que fazem um pregador, representadas nas partes do versículo supracitado. Dessa forma, após estabelecer que a palavra de Deus não produz frutos, não por falha de Deus, nem pelos ouvintes, mas por erros dos pregadores, Vieira principia a investigação da causa, elaborando cinco etapas: a Pessoa ("o que semeia"), a Ciência ("semear"), a Matéria ("semente"), o Estilo ("sua") e a Voz (representada no versículo que encerra a parábola: "Dizendo ele essas coisas, clamava: Quem tiver ouvidos para ouvir, ouça"). Assim, no próprio texto, todos esses volteios verbais produzidos encontram-se dispostos em elementos sucessivos, de modo que, quando são transpostos em HQ, as relações se vão estabelecendo de modo coeso e coerente. Na sucessão de claves proposta pelo padre está, também, o guia a ser percorrido pela adaptação.

Pensando-se no sermão não mais restrito a um gênero da oralidade e retórico, mas como uma narrativa desenvolvida em torno de uma tese a ser defendida, a adaptação para HQ torna-se possível pelo conjunto de argumentos e imagens dispostos em jogo, em paralelo ou em sucessão. Algo que se pode verificar nas conexões que esse gênero produz para a construção da história. Segundo Barbara Postema,

\begin{abstract}
A narrativa entra nos quadrinhos como um código: fragmentos de ação e eventos são representados e baseados nas relações entre esses fragmentos, como a causalidade, a progressão, ou outra forma de organização; os momentos separados nos quadros vêm para inferir um fluxo de eventos, um plano de ação. (POSTEMA, 2018, p. 91)
\end{abstract}

Com isso, na transposição de um texto narrativo para os quadrinhos, ela se delineia conforme a própria evolução do enredo: a situação inicial dos personagens, o surgimento de um conflito que demanda uma ação, o crescimento dessa ação até que se atinja o clímax e o desfecho. Pode-se perceber essa evolução narrativa em, pelo menos, dois níveis de leitura, conforme Will Eisner descreve em Quadrinhos e arte sequencial: "Nas histórias em quadrinhos, existem na verdade dois 'quadrinhos': A página total, que pode conter vários quadrinhos, e o quadrinho em si, dentro do qual se desenrola a ação narrativa. Eles são o dispositivo de controle na arte sequencial" (EISNER, 1999, p. 41). Funcionando como arcos de sentido, compreende-se cada quadrinho como uma unidade - o leitor decodifica a disposição de seus elementos e interpreta a mensagem proposta 
-, mas, sendo parte de uma página, cria-se um arco maior como visão geral, com cada quadrinho funcionando como um elemento disposto dentro de uma mensagem mais ampla. As páginas, por sua vez, também são etapas dentro da HQ como um todo, sendo ela, também, um arco narrativo da história global.

No caso de um sermão vieiriano, é necessário desvendar a linha de raciocínio do padre em torno de sua tese, apresentada no exórdio. Tais relações, também se vão estabelecendo em diversos níveis de "quadros": há o conceito norteador (celebração do evento do calendário litúrgico ou evocação apologética de santos) e o versículo bíblico exposto em premissa maior, como unidade macro; há a divisão do conceito em partes, usualmente expostas em "capítulos", em que cada capítulo corresponde a uma etapa analítica do conceito; há a subdivisão de cada parte em argumento (ou argumentos), a defender ou a refutar a premissa menor apresentada; há a ilustração, por meio de exemplos bíblicos, socioculturais ou da natureza, de tais argumentos, criando micro-histórias associadas à discussão encetada.

Nessa gradação espelha-se a própria estrutura de articulação que Santo Inácio de Loyola estabelecia em seus escritos. Conforme análise de Roland Barthes, em leitura dos Exercícios espirituais inacianos:

\footnotetext{
Quem quer que leia os Exercícios percebe à primeira vista que sua matéria está submetida a uma separação incessante, meticulosa e como que obsessional; ou, mais exatamente, os Exercícios são essa separação mesma a que nada preexiste; tudo é imediatamente dividido, subdividido, numerado em anotações, meditações, semanas, pontos, exercícios, mistérios etc. (BARTHES, 1990, p. 52, grifos nossos).
}

Tais construções verbais são definidas pelo crítico francês como "articulações", ou seja, elementos que tendem a se complementar, equilibrar e harmonizar o todo do discurso. É o que ocorre, por exemplo, no caminho empreendido nos sermões elaborados para as quatro domingas do Advento, pregados no ano de 1650. Como nos exercícios de Santo Inácio, distribuídos ao longo de cinco semanas, António Vieira desenvolverá sua argumentação em torno da preparação para o Natal (primeira vinda de Cristo) e do Juízo Final (segunda vinda de Cristo). Para isso, elegerá quatro pontos de vista sobre os julgamentos, que se vão complementando a cada sermão semanal: na Primeira Dominga, o Juízo de Deus; na Segunda, o Juízo dos homens; na Terceira, o Juízo de si mesmo; e, na Quarta, o Juízo dos Juízos precedentes.

Estabelece-se o Juízo de Deus no sermão da Primeira Dominga do Advento, tomando como base o versículo do Evangelho de Lucas, que trata, precisamente, do início da segunda vinda de Cristo: "Então verão o Filho do Homem vir sobre uma nuvem com grande poder e majestade" (LUCAS, 21, 27). Tanto o sermão, quanto a HQ, desenvolvem-se não no sentido de ilustrar o que será o Apocalipse ou o Inferno, mas no de evidenciar dois dos principais pecados a serem julgados: a omissão e a consequência.

Após o Juízo de Deus, António Vieira desloca-se para um nível abaixo e elege o Juízo dos Homens para o sermão da Segunda Dominga do Advento. A partir da história da prisão de João Batista, apresentam-se cinco razões para provar que os homens julgam de modo mais rigoroso e terrível do que Deus: 1) Deus julga com o entendimento, os homens julgam com a vontade; 2) No juízo de Deus, basta o testemunho da própria consciência, no dos homens, prevalece a calúnia contra a verdade; 3) No juízo de Deus, as boas obras de alguém tornam-se elemento favorável a ele, no dos homens, servem para impulsionar a inveja e um julgamento tendencioso; 4) Deus julga o que conhece, os homens julgam o que não conhecem; 5) No juízo de Deus, a sentença se diz no Juízo Final, no dos homens, a todo momento se elaboram 
sentenças inamovíveis. No início da HQ correspondente, faz-se menção à história anterior como forma de estabelecer-se a ponte de conexão em um arco maior. Na sequência, como o próprio Vieira, no sermão, analisa cada uma das cinco razões acima, a partir de trechos bíblicos e exemplos práticos, optouse por empreender o mesmo movimento, ilustrando as etapas na mesma proporção do sermão.

O sermão da Terceira Dominga do Advento, por sua vez, fará novo mergulho, mas voltado ao Juízo de si mesmo. A partir do duplo questionamento que embaixadores de Jerusalém fizeram a João Batista: “Quem és tu? (...) Que dizes de ti mesmo?” (JOÃO, 1, 19-22), Vieira efetua um percurso para mostrar que toda pessoa comete um duplo engano nas respostas dadas a essas perguntas, precisamente por haver uma grande distinção entre o que se é e o que se acredita ser. O pregador parte das perguntas ao Batista, e estabelece como tese: "Que diferentes coisas são ordinariamente o que dizeis de vós, e o que sois! E o pior é que muitas vezes não são coisas diferentes: porque o que sois é nenhuma coisa, e o que dizeis são infinitas coisas." (VIEIRA, 2014, pp. 246-7). Na HQ, por sua vez, apresentam-se as três perguntas dos embaixadores que Vieira problematiza: "És o Messias?”, "És Elias?”, "És profeta?”. A essas perguntas, todas negadas, João Batista responde: "Eu sou uma voz que clama no deserto", levando-se à conclusão de que o que vale não são os nomes nem o julgamento de si, mas sim as ações que se realizam.

Por fim, o Sermão da Quarta Dominga do Advento funciona como síntese do percurso empreendido até então pelos três anteriores. No início da HQ, efetua-se a síntese dos três sermões anteriores:
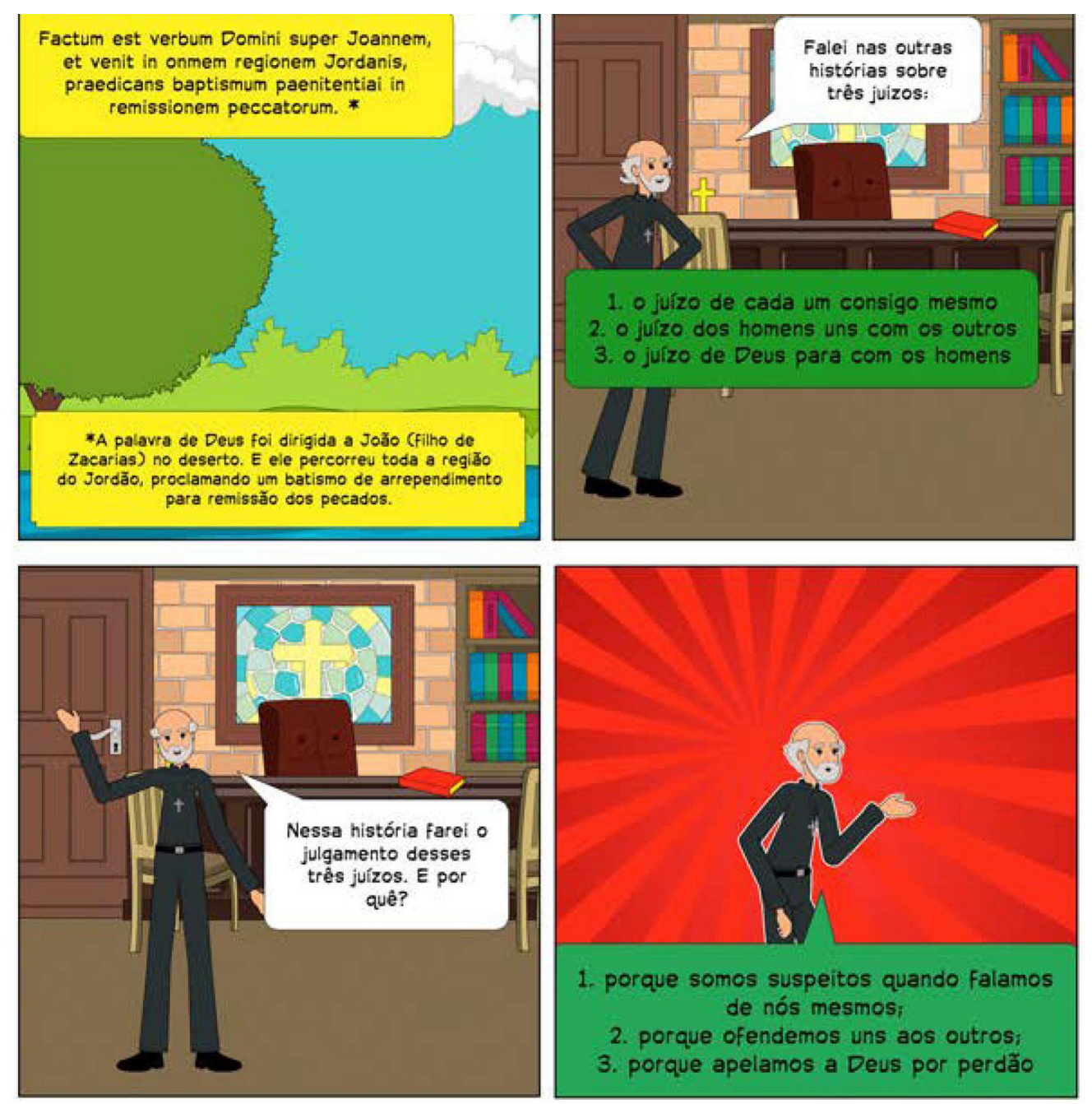

Figura 2: Quadrinhos da HQ Sermão da Quarta Dominga do Advento (1650), página 1 
$\mathrm{Na}$ sequência, ilustrando-se com um “Tribunal da Penitência”, formula-se o julgamento da personificação das três Domingas prévias, talvez no mais teatral dos sermões apresentados. O padre Vieira faz uso de elementos retóricos e expressões dramáticas em seu sermão, como se nota logo no início da segunda parte: "Ora venham entrando os três juízos, para serem examinados e julgados no tribunal da Penitência: o juízo de si mesmo, para que se emende, o juízo dos homens, para que se despreze, o juízo de Deus, para que se revogue; e comecemos pelo que nos fica mais perto" (VIEIRA, 2014, p. 269). Nessa espécie de jogo de cena - também realizada, por exemplo, no sermão da Primeira Dominga, com o padre explicitando que precisaria trazer aos presentes um condenado do inferno, para conseguir transmitir realmente o que seriam os castigos dos pecadores -, António Vieira concatena as palavras para que ilustrem o seu pensamento, dando ênfase e movendo a sua audiência ao caminho que deseja.

Como António José Saraiva aponta, a movimentação cênica que Vieira realiza em seus sermões

É, de certa maneira, o espetáculo absoluto, a ambição secreta de todo grande artista, isto é, espetáculo em que não existem atores e espectadores. O público não é público porque participa da peça: o protagonista representa como se fosse um papel de ator a paixão que ele próprio sente; as personnae dramatis não o são, pois objetivamente constituem o destinatário e o emissor da mensagem. Tudo é espetáculo ou nada o é, conforme o ponto de vista. (SARAIVA, 1980, p. 98)

Assim, a adaptação dos sermões para os quadrinhos deve buscar criar correlatos cênicos para os jogos verbais do jesuíta. No prefácio da editio princeps, o padre Vieira declara que seus sermões postos em texto se limitariam a "borrões, que sem a voz que os animava, ainda ressuscitados, são cadáveres" (VIEIRA, 2015, p. 285). No caso das HQs, tal "ressurreição" tenciona transmitir não somente uma pretensa voz sugerida pela expressividade do personagem da ilustração, mas também representar a vida neles pressentida nos exemplos dispostos nos sermões. Os balões de fala, os cortes de cena e evolução nos quadrinhos, bem como a interação com o cenário e demais personagens tendem a fornecer ao leitor um modo de conferir alma e dinamismo à letra morta do texto.

$\mathrm{Na}$ construção das HQs do projeto, tal era o eixo motivador: expor a argumentação vieiriana de modo a evidenciar a atualidade e versatilidade da linguagem para um público em idade escolar. Para isso, a arquitetura lógica criada por Vieira nas palavras deveria se associar à ideia visual de um personagem em diálogo e interação com os próprios raciocínios elaborados. Conforme Will Eisner aponta, sobre a união das duas linguagens:

\begin{abstract}
Ao escrever apenas com palavras, o autor dirige a imaginação do leitor. Nas histórias em quadrinhos imagina-se pelo leitor. (...) Quando palavra e imagem se "misturam", as palavras formam um amálgama com a imagem e já não servem para descrever, mas para fornecer som, diálogo e textos de ligação. (EISNER, 1999 , p. 122).
\end{abstract}

Pensando-se nessa fusão, exemplificada a seguir com a sequência da HQ do Sermão da quarta dominga do Advento, foi necessário criar personagens que representassem os três juízos elaborados pelo padre nos sermões anteriores. Para isso, da mesma forma que no sermão cada um deles é exposto e analisado individualmente, os quadrinhos também fazem tal apresentação, com ares teatrais de exposição. Percebe-se, nos termos usados por Vieira na definição do juízo de si mesmo, como os recursos cênicos se mostram: "Entra com os olhos tapados, porque não há juízo mais cego. A cegueira do juízo, e amor-próprio é muito maior, que a cegueira dos olhos: a cegueira dos olhos faz que não vejamos as coisas, a cegueira do amor-próprio faz que as vejamos diferentes do que são: que é muito maior cegueira." (VIEIRA, 2014, p. 270). Na 
HQ, optou-se por manter frases objetivas e pontuais, tanto para que o raciocínio fosse mais prontamente entendido, quanto pela razão prática de não existir um balão de fala de tamanho excessivo, comprometendo o componente imagético do quadrinho e diminuindo os pontos focais de cada quadrinho:
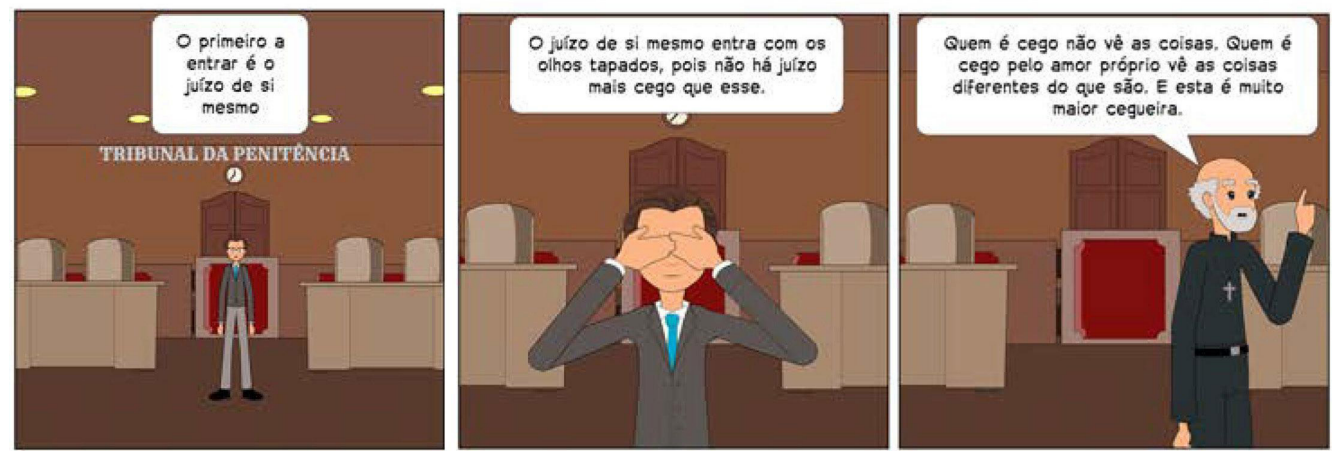

Figura 3: Quadrinhos da HQ Sermão da Quarta Dominga do Advento (1650), página 2

Como mencionado anteriormente, o cenário escolhido para os lances teatrais de Vieira "trazer a público" os três juízos foi um tribunal, criando essa associação de julgamento, havendo, inclusive, o personagem da Penitência, a decretar a palavra final aos três. No caso desse primeiro, decidiu-se por ilustrá-lo com as mãos fechando os olhos - embora não especificado no texto original -, uma vez que tal ação se torna mais significativa do que uma venda ou outro objeto. Complementando a ideia presente no sermão, de que o juízo de si mesmo é o mais cego dos juízos, demonstra-se que o ato de se fazer cego parte do próprio indivíduo, e não de outro que lhe impusesse tal cegueira. Assim, nessa forma de "imaginar pelo leitor", busca-se acrescentar um pormenor ao texto expandindo-o em um novo sentido.

O inverso também pode ocorrer, como, por exemplo, na comparação entre o texto parenético que descreve a entrada do segundo dos juízos e dos quadrinhos correlatos:

Entra pois o juízo dos homens a apresentar-se diante do tribunal da Penitência: e não vem com os olhos vendados, como o juízo de si mesmo; mas com todos os sentidos, e com todas as potências livres, e muito livres; porque com todas julga a todos. Traz livres os olhos, porque julga tudo o que vê; traz livres os ouvidos, porque julga tudo o que ouve; traz livre a língua, porque publica tudo o que julga; e traz livre mais que tudo a imaginação, porque julga, e condena tudo o que imagina. (idem, p. 276)
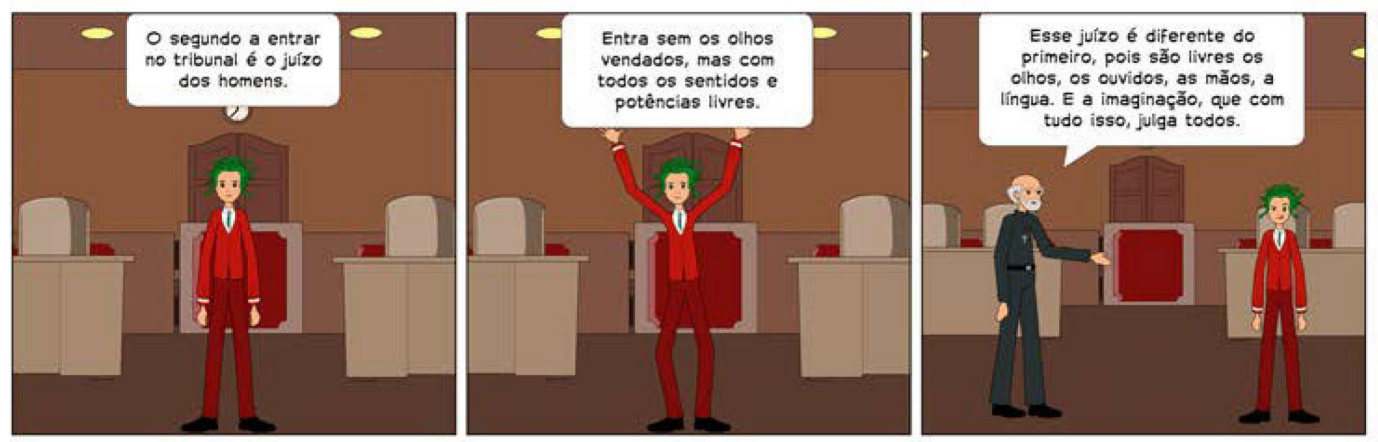

Figura 4: Quadrinhos da HQ Sermão da Quarta Dominga do Advento (1650), página 3

Nota-se que, no sermão, António Vieira formula, seguindo uma estrutura sintática paralelística e derivativa, a caracterização do segundo juízo a partir de elementos físicos e dos sentidos (olhos, ouvidos, língua e imaginação). Nos quadrinhos, julgou-se que tal replicação dos jogos visuais e sinfônicos nos quadrinhos poderia ser um elemento em revés, pois, diante do fato de que há diversos outros formulados 
na sequência e em outras partes do sermão, foi preciso sintetizar ou suprimir alguns, para que a dimensão da HQ não ficasse demasiado extensa. Por isso, e obedecendo à mesma estrutura elaborada na apresentação do primeiro juízo, criou-se a sequência de três quadros, para a revelação do segundo juízo e definição do próprio Vieira, de modo mais sucinto.

O último personagem apresentado é o juízo de Deus e, para a HQ, optou-se pela representação arquetípica de Deus (a partir dos recursos disponíveis na plataforma de criação Pixton). Em tal juízo, não se inseriu a figura de Vieira descrevendo, mas sim uma representação abstrata do surgimento do Deusjuiz:
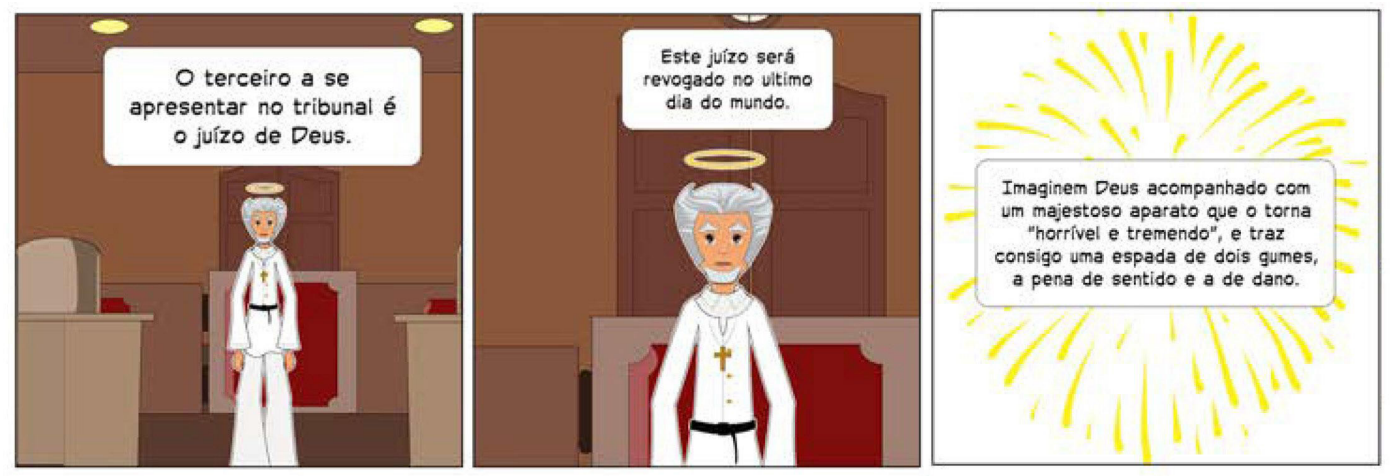

Figura 5: Quadrinhos da HQ Sermão da Quarta Dominga do Advento (1650), página 4

No texto do sermão, esse terceiro juízo é formulado seguindo uma argumentação pautada por um autoquestionamento retórico:

Do juízo de Deus não sei como me atreva a dizer outro tanto. Não é o juízo de Deus aquele juízo supremo, que
não só não reconhece superior, mas nem pode ter igual no Céu, nem na terra? Não é o juízo de Deus, de que
falamos, aquele último, e universal juízo, onde sem apelação, nem agravo, se hão de absolver, ou condenar para
toda a eternidade aqueles, que nele forem julgados, que hão de ser todos os homens? Pois como pode ser que
haja outro tribunal no mundo em que a sentença deste juízo se revogue; ou como pode ser revogar-se? (idem,
p. 282)

Com isso, António Vieira evoca o juízo de Deus como a última e maior instância, o que acaba por criar um discurso de aparente contradição: se o juízo de Deus é inapelável e indiscutível, como será possível ser revogado? A resposta, dada por ele mesmo na sequência, é de que todo arrependimento apresentado ao tribunal da Penitência terá a pena revogada no juízo de Deus. Usando do exemplo de Jonas (também ele adaptado como "história dentro da história" na HQ), Vieira mostra como a destruição de Nínive profetizada não aconteceu, pois todos se arrependeram antes do prazo de quarenta dias. Dessa forma, na construção dos três juízos e resgatando elementos das três histórias anteriores, chega-se à conclusão de que toda ação e todo pensamento devem ser dirigidos para que não se prejudique a si mesmo, ao próximo e a Deus.

Essas escolhas, nas ações do projeto de criação das histórias em quadrinhos, estimulam os bolsistas e voluntários a efetuarem uma leitura crítica e analítica do texto-base, ao mesmo tempo em que devem conscientemente selecionar as diretrizes e encaminhamentos da adaptação, tanto do texto verbal, quanto do texto imagético concomitante. Por certo que, em se tratando de um texto de cunho religioso, as noções de espiritualidade tornam-se elemento fulcral e continuamente presente. Mas todas as atividades têm vistas muito mais à linguagem empregada e aos raciocínios desenvolvidos do que a uma "doutrinação". 
E isso, no caso dos textos do padre António Vieira, torna-se algo salutar e necessário, uma vez que tal autor era leitura fundamental de escritores como Fernando Pessoa ou José Saramago, nomes que viam em Vieira o artífice-mor da língua portuguesa.

O uso da adaptação de textos clássicos para histórias em quadrinhos, conforme já apontado, torna-se importante ferramenta para o ensino de literatura. Mas, visando-se a um trabalho mais aprofundado, é preciso formular-se, primeira e principalmente, pelo mergulhar no texto, buscando as nuances e aguçando curiosidades, de modo a convidar o aluno-leitor a interagir com o texto, desvendando meios de descoberta e interação para além da leitura tradicional e solitária do texto impresso.

Os sermões em histórias em quadrinhos, enfim, intentam realizar mais uma representação da articulação verbal vieiriana, com vistas a uma compreensão geral da arquitetura interna de um texto. Ao fim e ao cabo, o intuito é estimular a percepção de que um texto, seja ele um sermão produzidono séculoXVII, umaHQ, umadissertação ou um bilhete, possui a mesma necessidade de conexão entre as palavras e os sentidos que o compõem. Barbara Postema salienta que "para que os leitores aprendam a entender integralmente os quadrinhos, devem ter em mente o todo, ou a 'coerência global', uma vez que são eles que fazem o trabalho de interpretação dos vários signos em uma obra em quadrinhos." (POSTEMA, 2018, p. 31). Assim sendo, pensando-se em cada quadrinho como peça detentora de uma parte da mensagem, o trabalho com a leitura e a produção textual desse gênero deve ser desenvolvido em torno dos espaços narrativos criados, dos gaps de inferência como forma de articulação entre os quadrinhos e, não menos importante, do componente lúdico na visualidade que as imagens acabam por estimular.

Nesse sentido, é preciso aliar a abordagem da leitura da HQ com um espaço para novas perspectivas de compreensão. Trazer os sermões vieirianos (ou outros de igual complexidade) sob essa nova roupagem é uma forma de aproximar a obra canônica dos contextos de produção e de repertório dos alunos, propiciando uma interação com o professor exercendo o papel de mediador e incentivador.

Marisa Lajolo, em "O texto não é pretexto. Será que não é mesmo?”, revê a questão do uso dos diferentes gêneros textuais em sala de aula, apontando que todo texto se torna deslocado de seu contexto original, para ser revisto sob a óptica da análise linguística e literária. Para a autora,

\begin{abstract}
Nesse distanciamento, é mais fácil desenvolverem categorias críticas de leitura para que, em situações comuns, exteriores à escola, os alunos possam ser sujeitos críticos da leitura que fazem de tais textos. Ou seja: a migração de textos para atividades escolares subtrai os textos de seu - digamos - gênero original. Mas isso é inevitável: textos sã̃o migrantes por natureza, e a migração não ocorre apenas em situação escolar. (LAJOLO, 2009, p. 106)
\end{abstract}

No caso de António Vieira, dificilmente um aluno, por própria iniciativa, buscará os seus sermões para ler. Então, assim como ocorre com outros escritores, o conhecimento de suas obras e seu estilo restringe-se às leituras realizadas nos bancos escolares. Ainda, reinserindo os sermões em um novo suporte, os quadrinhos, pode-se criar nessa "migração" um campo de diálogo para as mudanças sociais, históricas que se denotam entre o século XVII e o século XXI, bem como as constantes humanas que permanecem e que são apontadas por Vieira. Aproveitando-se de que a linguagem visual e dinâmica das HQs desperta o interesse de crianças e adolescentes, usar essa ferramenta como ponte para outros gêneros, como a parenética, é uma forma de vislumbrar, inclusive, trabalhos e discussões escolares concernentes à argumentação, ao encadeamento lógico e à retórica. Assim, os alunos se podem reconhecer tanto como sujeitos-leitores, quanto elementos de uma 
coletividade, composta a partir da reverberação de todas as épocas precedentes.

Tendo como diretriz básica as novas tecnologias como método de estimular um diálogo com a tradição, os produtos gerados por essa pesquisa buscam trazer a lume a função primordial do pensamento vieiriano, expresso em seus escritos, e que, mesmo mais de três séculos após sua morte, ainda se mantém atual: a palavra como objeto de ação na formação de um leitor consciente. A história em quadrinhos, portanto, com a interação da palavra com a imagem, tornase um importante estímulo para simbolizar o valor do raciocínio na construção de argumentos e as conexões e associações possíveis com outros campos de sentido, criando estratégias narrativas e criando novas formas de leitura.

\section{Referências bibliográficas}

BARTHES, Roland. Sade, Fourier, Loyola. São Paulo: Brasiliense, 1990.

EISNER, Will. Quadrinhos e arte sequencial. São Paulo: Martins Fontes, 1999.

HUTCHEON, Linda. Uma teoria da adaptação. Florianópolis: Editora UFSC, 2013.

JOÃO, In: BÍBLIA Sagrada. São Paulo: Edições Paulinas, 1977. Cap. 1, vers. 19-22, p. 1156.

LAJOLO, Marisa. “O texto não é pretexto. Será que não é mesmo?” In: ZILBERMAN, Regina \& RÖSING, Tania M. K. (orgs), Escola e leitura velha crise, novas alternativas. (pp. 99-112). São Paulo: Global, 2009.

LUCAS, In: BÍBLIA Sagrada. São Paulo: Edições Paulinas, 1977. Cap. 21, vers. 27, p. 1148

POSTEMA, Barbara. Estrutura narrativa nos quadrinhos. São Paulo: Peirópolis, 2018.
SARAIVA, António José. O discurso engenhoso. São Paulo: Perspectiva, 1980.

VIEIRA, António. Sermões do Advento, do Natal e da Epifania. São Paulo: Edições Loyola, 2014.

Sermões e discursos vários. São Paulo: Edições Loyola, 2015

WIELEWICKI, Vera Helena Gomes; PRADO, Márcio Robertodo. "Literatura emultimodalidades". In: BONNICI, Thomas; ZOLIN, Lúcia Osana (orgs.) Teoria literária: Abordagens históricas e tendências contemporâneas. Maringá: EDUEM, 2019.

Submissão: agosto de 2020 . Aceite: novembro de 2020. 